\title{
elF4G2 balances its own mRNA translation via a PCBP2-based feedback loop
}

\author{
VICTORIA V. SMIRNOVA, ${ }^{1,2}$ EKATERINA D. SHESTAKOVA, ${ }^{3}$ DMITRY V. BIKMETOV, ${ }^{1}$ \\ ANASTASIA A. CHUGUNOVA, $, 4,5$ ILYA A. OSTERMAN, ${ }^{2,4,5}$ MARINA V. SEREBRYAKOVA, ${ }^{2}$ \\ OLGA V. SERGEEVA, ${ }^{5}$ TIMOFEY S. ZATSEPIN, ${ }^{5}$ IVAN N. SHATSKY, ${ }^{2}$ and ILYA M. TERENIN ${ }^{2,6}$ \\ ${ }^{1}$ Faculty of Bioengineering and Bioinformatics, Lomonosov Moscow State University, Leninskie Gory, 119234 Moscow, Russia \\ ${ }^{2}$ Belozersky Institute of Physico-Chemical Biology, Lomonosov Moscow State University, Leninskie Gory, Moscow 119992, Russia \\ ${ }^{3}$ Department of Biochemistry, School of Biology, Lomonosov Moscow State University, Leninskie Gory, Moscow, 119234, Russian Federation \\ ${ }^{4}$ Chemistry Department, Lomonosov Moscow State University, Leninskie Gory, Moscow 119991, Russia \\ ${ }^{5}$ Skolkovo Institute of Science and Technology, Skolkovo, Moscow Region 143026, Russia \\ ${ }^{6}$ Sechenov First Moscow State Medical University, Institute of Molecular Medicine, 119991, Moscow, Russian Federation
}

\begin{abstract}
Poly(rC)-binding protein 2 (PCBP2, hnRNP E2) is one of the most abundant RNA-binding proteins in mammalian cells. In humans, it exists in seven isoforms, which are assumed to play similar roles in cells. The protein is shown to bind $3^{\prime}$-untranslated regions ( $3^{\prime}$-UTRs) of many mRNAs and regulate their translation and/or stability, but nothing is known about the functional consequences of PCBP2 binding to $5^{\prime}$-UTRs. Here we show that the PCBP2 isoform $f$ interacts with the $5^{\prime}$-UTRs of mRNAs encoding elF4G2 (a translation initiation factor with a yet unknown mechanism of action, also known as DAP5) and Cyclin I, and inhibits their translation in vitro and in cultured cells, while the PCBP2 isoform e only affects Cyclin I translation. Furthermore, elF4G2 participates in a cap-dependent translation of the PCBP2 mRNA. Thus, PCBP2 and elF4G2 seem to regulate one another's expression via a novel type of feedback loop formed by the translation initiation factor and the RNA-binding protein.
\end{abstract}

Keywords: translational control; ribosomal scanning; $\alpha \mathrm{CP} 2$

\section{INTRODUCTION}

The mechanism of translation initiation in eukaryotes was established about two decades ago when Marilyn Kozak's scanning model was complemented with a biochemical characterization of the initiation factors' activities (for reviews, see Hinnebusch 2011, 2014). Since then, this basement has not been shaken, although there are numerous cases that do not fit this model particularly well. elF4G2 (also DAP5, Nat1) is one of such square pegs in a round hole of our knowledge of eukaryotic translation initiation. The protein seems to be present in all Chordata and many (but clearly not all) invertebrates. Despite its close homology with elF4G1, elF4G2 lacks binding sites for elF4E and PABP (Imataka et al. 1997; Levy-Strumpf et al. 1997; Shaughnessy et al. 1997; Yamanaka et al. 1997) and thus it is believed to have a hand in cap-independent translation of certain cellular mRNAs (Henis-Korenblit et al. 2002;

Corresponding authors: terenin@belozersky.msu.ru, shatsky@ belozersky.msu.ru

Article is online at http://www.rnajournal.org/cgi/doi/10.1261/rna. 065623.118.
Hundsdoerfer et al. 2005; Lewis et al. 2008; Marash et al. 2008), although a stimulatory action of elF4G2 on cap-dependent translation was also reported (Lee and McCormick 2006; de la Parra et al. 2018). The protein is essential for development in mouse (Yamanaka et al. 2000), zebrafish (Nousch et al. 2007), and Drosophila (Yoshikane et al. 2007), probably because of its participation in the translation of differentiation-associated proteins (Yoffe et al. 2016; Sugiyama et al. 2017), and its overexpression in ES cells leads to a spontaneous differentiation (Takahashi et al. 2005). Remarkably, to date, no organism is known whose elF4G2 mRNA uses an AUG triplet as an initiator codon. In apparently most (if not all) vertebrates, it is GUG, while in Insecta, Mollusca, or simple Chordata, no translation initiation site can be assigned unambiguously. Such an evolutionarily conserved mRNA feature implies the

(C) 2019 Smirnova et al. This article is distributed exclusively by the RNA Society for the first 12 months after the full-issue publication date (see http://rnajournal.cshlp.org/site/misc/terms.xhtml). After 12 months, it is available under a Creative Commons License (Attribution-NonCommercial 4.0 International), as described at http:// creativecommons.org/licenses/by-nc/4.0/. 
existence of posttranscriptional regulation. It is now widely recognized that any mRNA is heavily packed with the bound proteins (Baltz et al. 2012; Castello et al. 2012; Beckmann et al. 2015; Hentze et al. 2018), and since every known case of posttranscriptional regulation relies on mRNA-binding proteins, we sought to identify the proteins that interact with the human elF4G2 mRNA.

Poly( $\mathrm{rC}$ )-binding proteins (hnRNP K and PCBP1-4) are important actors in mRNA metabolism. They participate in splicing (Expert-Bezançon et al. 2002; Ji et al. 2016; Grelet et al. 2017), transcription (Choi et al. 2009), translational repression, and stabilization or destabilization of mRNAs via an interaction with their 3'-UTRs (Scoumanne et al. 2011; Han et al. 2013; Ren et al. 2016). The two probably most known cases of their translation-related activities are the stabilization of $\alpha$-globin mRNA and the repression of ALOX15 mRNA translation during hematopoiesis (for review, see Ostareck-Lederer and Ostareck 2012). PCBP2 also participates in translation driven by the IRES element from poliovirus and other related viruses (Blyn et al. 1997; Gamarnik and Andino 1997; Graff et al. 1998; Walter et al. 1999; Sweeney et al. 2014; Asnani et al. 2016a). However, cases in which PCBP2 affects 5 '-end-dependent translation via binding to $5^{\prime}$-UTRs, are not explicitly described. In humans, at least seven PCBP2 isoforms (a-g) are known to exist. These isoforms arise from alternative splicing, but all PCBP2-coding mRNAs seem to possess the same 5'-UTR. To date, no functional difference between the isoforms has been registered.

Here we show that the PCBP2 isoform $\mathrm{f}$ binds the $5^{\prime}$-UTR of the elF4G2, and the PCBP2 isoforms e and $f$ bind the $5^{\prime}$-UTR of the Cyclin I (CCNI) mRNAs in vitro and inhibit the translation of the corresponding reporter mRNAs, while the PCBP2 knockdown in 293T or Huh7 cells augments their translation. Strikingly, knockdown of the elF4G2 gene in NIH/3T3, 293T, or Huh7 cells leads to a significantly decreased translation driven by the $5^{\prime}$-UTR of the PCBP2 mRNA as well as the PCBP2 protein level. Thus, elF4G2 and PCBP2 mutually tune one another's translation.

\section{RESULTS AND DISCUSSION}

\section{Proteins that bind the $5^{\prime}$-UTR of the elF4G2 mRNA}

First, we sought to identify proteins that interact with the elF4G2 mRNA. The 5'-UTR and 3'-UTR of the human elF4G2 mRNA (transcript variant 1) were cloned upstream and downstream from the firefly luciferase coding sequence, respectively, to create a pGL3-elF4G2 plasmid that was used further for the reporter mRNA and the biotinylated bait synthesis. The authentic $5^{\prime}$ boundary of the 5'-UTR was defined on the basis of expressed sequence tags (EST) and cap-assisted gene expression analysis (CAGE) data (Severin et al. 2014). Since the evolutionarily conserved GUG initiator codon is most likely important for the regulation of elF4G2 expression, we included it and started 30 nucleotides ( $n t)$ of the elF4G2 coding region in the reporter. Additionally, the firefly luciferase AUG codon was mutated to exclude any contribution of the translation initiation downstream from the suboptimal authentic elF4G2 start codon.

In vitro transcribed noncapped biotinylated RNA, corresponding to the human elF4G2 5'-UTR, was used to pull down proteins from HeLa cytoplasmic extract (Fig. 1, left lane). The proteins specifically bound to the elF4G2 5'-UTR were identified by mass spectrometry as hnRNP K, HuR, SERBP1, YBX3, PCBP2, and PTBP1. YBX1 and hnRNP $Q$ are ubiquitously bound to any RNA tested (Fig. 1 ; also, data not shown). Similarly to the case of poliovirus IRES (Blyn et al. 1995, 1996, 1997; Andreev et al. 2012), PCBP2 manifests itself in the multiple bands, reflecting the diversity of its isoforms.

\section{PCBP2 $f$ inhibits translation of the reporter mRNA bearing the elF4G2 $5^{\prime}$-UTR in vitro}

All the identified proteins except for YBX3, the cDNA of which we have failed to amplify from a dozen different cDNA preparations, were cloned and expressed in Escherichia coli. We accidentally amplified cDNAs corresponding to two isoforms of the PCBP2, viz., PCBP2e and PCBP2f. Thus, both were studied. We addressed whether the addition of either protein affects translation of the elF4G2 reporter mRNA in vitro in Krebs-2 cytoplasmic extract. While SERBP1, hnRNP K, HuR, PCBP2e, or PTBP1 exert no specific effect (data not shown) on the translation of a dozen of reporter mRNAs tested, including the elF4G2 reporter, the other PCBP2 isoform, PCBP2f, inhibits the

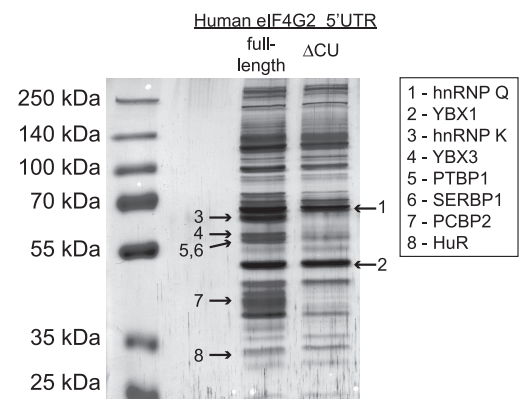

FIGURE 1. Identification of the proteins bound to the $5^{\prime}$-UTR of the elF4G2 mRNA. In vitro transcribed biotinylated noncapped RNAs corresponding to either the human elF4G2 $5^{\prime}$-UTR or its deletion mutant lacking the polypyrimidine tract (199-274 nt of the elF4G2 $5^{\prime}$-UTR, elF4G2 $\Delta \mathrm{CU}$ ) were soaked in HeLa cytoplasmic extract, the complexes were purified via streptavidin-agarose chromatography, the bound proteins were resolved by SDS-PAGE, and identities of the specific bands were identified by LS-MS. Two major bands that bind to all mRNAs in our hands have been identified as YBX1 and hnRNP Q. PCBP2, PTBP1, YBX3, hnRNP K, and SERBP1 were found to interact with the polypyrimidine tract within the $5^{\prime}$-UTR of the elF4G2 mRNA. 
translation of the elF4G2 reporter mRNA and this effect does not depend on the presence of the authentic 3'-UTR sequence (Fig. 2A). Notably, closely related PCBP1 also has no effect on the translation of the elF4G2 reporter mRNA (data not shown).

\section{The polypyrimidine sequence within the $5^{\prime}$-UTR of the elF4G2 mRNA is necessary and sufficient for the PCBP2-mediated translation repression in vitro}

To map the PCBP2-binding site within the $5^{\prime}$-UTR of the elF4G2 mRNA, we have analyzed the ENCODE data set ENCSR339FUY, which represents the PCBP2 eCLIP data for HepG2 cells (ENCODE Project Consortium 2012). These data indicate that the polypyrimidine stretch in the middle of the elF4G2 mRNA 5'-UTR is the PCBP2-binding site. As expected, the deletion of the 78-nt-long polypyrimidine sequence (of which $72 \mathrm{nt}$ are $\mathrm{C}$ and $\mathrm{U}$ ) resulted in a loss of PCBP2 binding (Fig. 1, right lane). Notably, this $\mathrm{CU}$-rich region seems to be responsible for the binding of the whole bunch of the elF4G2 mRNA-specific proteins, because hnRNP K, PTBP1, YBX3, and SERBP1 also fail to bind this deletion mutant (elF4G2 $\triangle \mathrm{CU}$ ). This may suggest that some of these proteins function as a complex. Indeed, hnRNP K and PCBP1/2 are often bound to the same mRNA targets (Kiledjian et al. 1995; Ostareck et al. 1997; Collier et al. 1998; Thiele et al. 2004; Lee et al. 2007; Thyagarajan and Szaro 2008).

In contrast to the wild-type elF4G2 reporter mRNA, the translation of its deletion mutant is fully resistant to the PCBP2f addition in vitro (Fig. 2B). In a reciprocal approach, this CU-rich element was inserted into the late adenovirus tripartite leader (TPL) in either sense (TPL+) or antisense (TPL-) orientation. As we anticipated, translation of the $\mathrm{TPL}+$ reporter has become susceptible to the PCBP2fmediated inhibition in vitro (Fig. 2B).
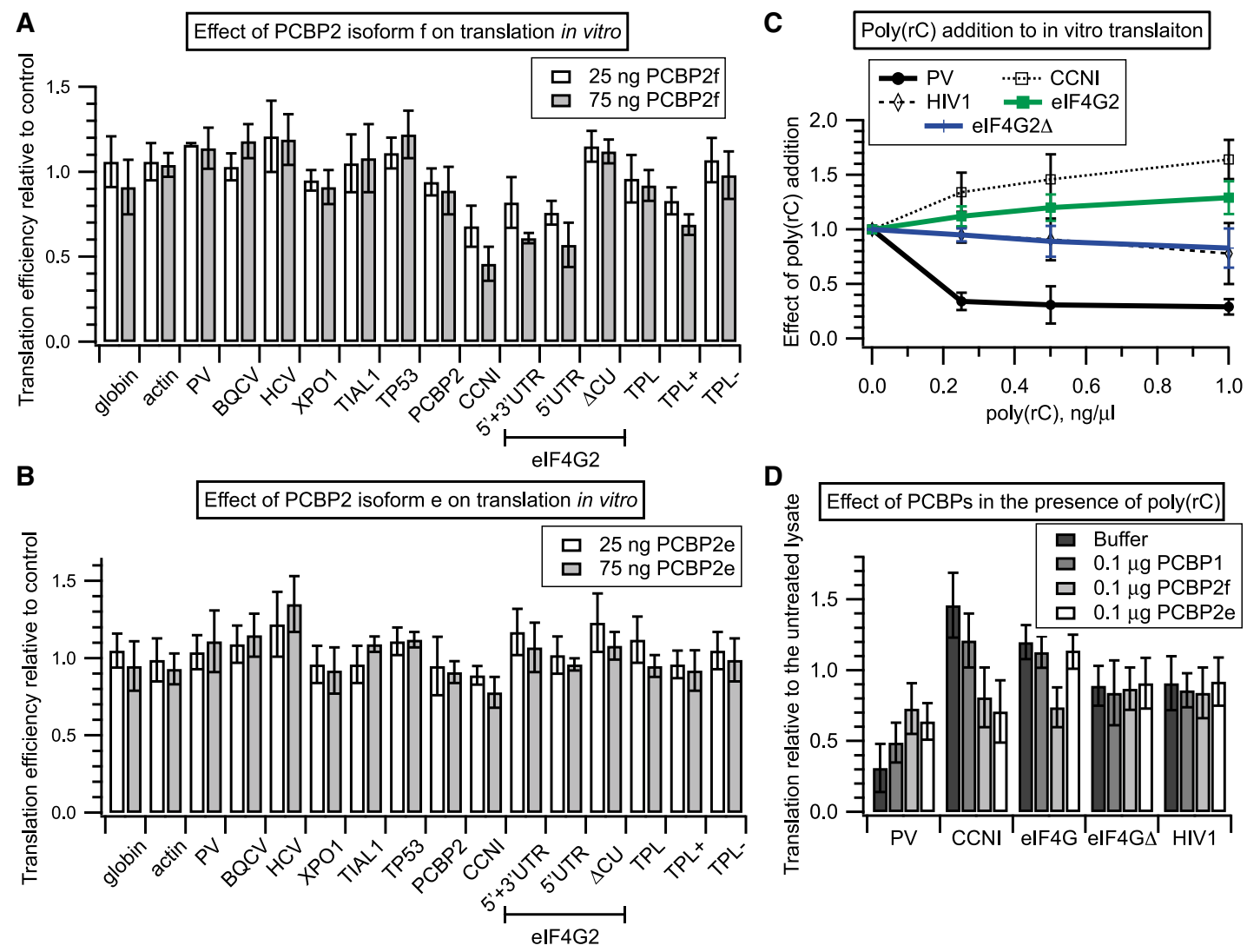

FIGURE 2. PCBP2 specifically inhibits translation in Krebs-2 cytoplasmic extract. In vitro transcribed $\mathrm{m}^{7} \mathrm{G}$-capped and polyadenylated mRNAs bearing the indicated $5^{\prime}$-UTRs and encoding Fluc or Nluc in the case of the CCNI reporter were translated for 40 min in Krebs-2 cytoplasmic extract in the presence of the indicated amounts $(25 \mathrm{ng}$ or $75 \mathrm{ng}$ ) of the recombinant PCBP2 isoforms, and then the luciferase activity was measured. Bars show the translation level relative to control reactions which contained PCBP2 storage buffer instead of the protein. The elF4G2 reporter contained either the authentic elF4G2 mRNA 3'-UTR (labeled 5' +3'-UTR) or SV40 3'-UTR (labeled 5'-UTR). (A) PCBP2e isoform. (B) PCBP2f isoform. Data are presented as mean with SD, five replicates at least. (C) Supplementation of translation reactions with the increasing amounts of poly(rC) inhibits the translation of the poliovirus reporter but augments the translation of the CCNI and elF4G2 reporters. Note that the elF4G2 reporter mutant that lacks the polypyrimidine stretch (elF4G2 $\Delta \mathrm{CU}$ ) is unresponsive to the poly(rC) addition. (D) Translation in Krebs-2 S30 lysate supplemented with $0.5 \mathrm{ng} / \mu \mathrm{l}$ poly $(\mathrm{rC})$ and the indicated amounts of either PCBP1 as control and PCBP2f of PCBP2e. Data from panels $C$ and $D$ are presented as mean with SD, four replicates. 


\section{Inhibition of Cyclin I translation by PCBP2 in vitro}

To address whether inhibition of translation by PCBP2 binding to $5^{\prime}$-UTRs is a more widespread phenomenon that is not limited to the case of the elF4G2 mRNA, we have further analyzed the eCLIP data (data sets ENCSR339FUY and ENCSR115GAA) published by the ENCODE Project (ENCODE Project Consortium 2012) and the iCLIP data from Flynn et al. (2015). We have selected the human CCNI, TIAL1, XPO1, and the murine PCBP2 5 '-UTRs (we have failed to amplify the human PCBP2 5'UTR sequence, thus highly homologous murine PCBP2 mRNA 5'-UTR was used) for further analyses on the basis of their deduced interaction with PCBP2. We also noticed that the eCLIP data suggest that PCBP2 is bound to the $3^{\prime}$-UTR of the TP53 mRNA. Thus, we cloned the corresponding $5^{\prime}$-UTRs upstream of the firefly luciferase coding sequence, and also the $5^{\prime}$-UTR and $3^{\prime}$-UTR of the TP53 mRNA in the case of the TP53 reporter upstream and downstream, respectively. The $5^{\prime}$-UTR of the CCNI mRNA was cloned upstream of a much brighter NanoLuc (Nluc) because, in our hands, the CCNI-Fluc reporter is translated very poorly compared to other mRNAs. Next, we translated all these reporters in vitro with the addition of either PCBP2e or PCBP2f. Among the corresponding reporters, only that with the $5^{\prime}$-UTR of the CCNI mRNA is sensitive to PCBP2 $f$ in vitro (Fig. 2A) and, unlike the elF4G2 case, this mRNA is also responsive to PCBP2e (Fig. 2B).

With respect to translation initiation, PCBP2's bettercharacterized role is to activate translation of the poliovirus and other related IRESes (Blyn et al. 1997; Gamarnik and Andino 1997; Graff et al. 1998; Walter et al. 1999; Sweeney et al. 2014; Asnani et al. 2016a,b), presumably acting as an RNA chaperone. Although translation of the poliovirus mRNA is strongly dependent on PCBP2 (Blyn et al. 1997; Gamarnik and Andino 1997; Sweeney et al. 2014), no effect of the PCBP2 addition is observed in the case of the poliovirus IRES-containing reporter (Fig. 2A, B). This, however, replicates earlier reports when the poliovirus mRNA was translated in HeLa cytoplasmic extract, and no effect of the PCBP2 addition could be seen until the lysate had been depleted of this protein (Blyn et al. 1997). PCBP2 is one of the most abundant RNA-binding proteins in a variety of cells (Hein et al. 2015; Uhlen et al. 2015), and it is apparently present at a saturating level already. To address this apparent contradiction, we supplemented the translation reactions with the increasing amounts of poly $(\mathrm{rC})$. In accordance with the earlier report (Walter et al. 1999), this results in a dose-dependent inhibition of the poliovirus IRES-driven translation (Fig. 2C), while the translation of the elF4G2 and CCNI reporters is stimulated by the poly $(\mathrm{rC})$ addition. The PCBP2-insensitive HIV1 and elF4G2 $\triangle \mathrm{CU}$ reporters are expectedly unresponsive to the poly $(\mathrm{rC})$ addition. The supplementation of the depleted lysate with either recombinant PCBP1, PCBP2f, or PCBP2e stimulates the translation driven by the poliovirus IRES, which recapitulates its dependence on the poly $(\mathrm{rC})$-binding proteins. Accordingly, the translation of the elF4G2 and CCNI reporter mRNAs is inhibited by the $\mathrm{PCBP} 2 \mathrm{f}$ addition, and the $\mathrm{CCNI}$ reporter also responds to the PCBP2e addition.

\section{Depletion of PCBP2 stimulates translation of the eIF4G2 and Cyclin I reporters in cultured cells}

In order to address how PCBP2 affects the translation of the selected mRNAs in cultured cells, we knocked down the PCBP2 gene in 293T or Huh7 cells (Fig. 3A,B). Sequences of the siRNAs have been designed so that all seven reported PCBP2 isoforms are targeted. In 293T cells, the translation of only two mRNAs shows statistically significant $(P$-values $<0.01)$ up-regulation compared to the $\beta$ globin or $\beta$-actin reporters, namely, elF4G2 and Cyclin I. Similar to the in vitro data, the $3^{\prime}$-UTR of the elF4G2 mRNA does not contribute to the PCBP2-sensitivity. Importantly, the translation of the elF4G2 reporter lacking the CU-tract is evidently unaffected. It should be noted that in our hands the PCBP2 knockdown in 293T cells inevitably leads to a drop (20\%-25\%) in a translatability of known PCBP2-unresponsive reporters; see, e.g., $\beta$-globin or $\beta$-actin (see Fig. 3A). This is also true for a couple of other siRNAs targeting PCBP2 (data not shown). In Huh7 cells, the drop is not observed. The set of the TPL-based reporters behaved in cells less pronounced than in the in vitro translation experiments. This is perhaps due to a very high activity of the TPL in promoting translation in cells or, at least partially, due to ribosomal shunting (Yueh and Schneider 1996) when a scanning ribosome bypasses PCBP2 bound to the 5'-UTR. Similar results were obtained with another siRNA against PCBP2 (data not shown).

In many cases, mRNA-binding proteins affect mRNA turnover. Since northern blotting or RT-qPCR are not able to analyze a transfected RNA stability (Barreau et al. 2006; Thomson et al. 2013), we opted for kinetics analyses of transfected mRNAs expression (Dmitriev et al. 2007; Andreev et al. 2009). The idea behind this approach is that accumulation of a reporter protein should slow down for a less stable mRNA compared to that for a more stable mRNA. Clearly, despite clearly different efficiencies, all the investigated mRNAs are translated with similar kinetics, arguing against a significant difference between their stabilities in Huh7 (Fig. 3D) or 293T cells (data not shown).

\section{elF4G2 participates in translation of PCBP2 mRNA}

Analysis of ribosome footprint profiling of $\mathrm{mES}$ (Sugiyama et al. 2017) and our own profiling of 293T and NIH/3T3 cells (which will be published elsewhere) revealed that the translation of the PCBP2 mRNA is inhibited upon the 

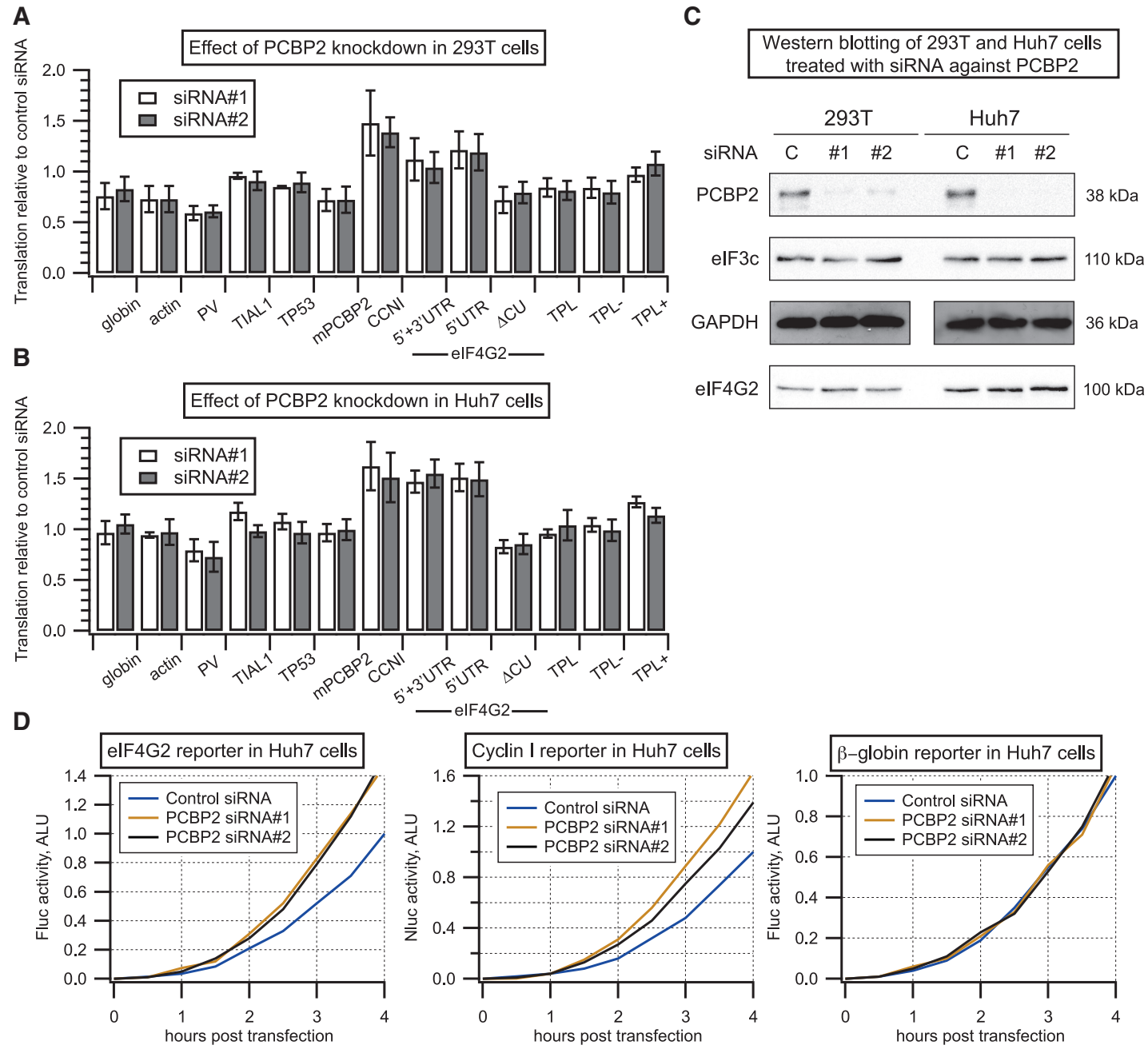

FIGURE 3. Effect of the PCBP2 knockdown on the translation of the selected reporter mRNAs. All the reporters bear Fluc except the CCNI reporter, which encodes NanoLuc. The reporters bearing the elF4G2 $5^{\prime}$-UTR are labeled as in Figure 2. Indicated in vitro transcribed $m^{7} G$-capped and polyadenylated reporters were transfected into cells pretreated with the siRNA against PCBP2 or with control siRNA. Bars show the translation level relative to control cells. (A) 293T cells. The translation of the TIAL1 reporter is reproducibly up-regulated relative to the $\beta$-globin or $\beta$-actin reporters, yet this up-regulation is statistically insignificant $(P$-value $>0.05)$. In the case of the CCNI/ $\beta$-globin pair, $P$-values are less than 0.0005 ; in the case of the DAP5/ $\beta$-globin pair, $P$-values are less than 0.01. For the TPL+/TPL and the TPL+/TPL- pairs, $P$-values are less than 0.05. At least five independent transfections have been performed. (B) Huh7 cells. For the DAP5/ $\beta$-globin reporters' pair, $P$-values are less than $0.00005(n=5)$. For the CCNI reporter, $P$-values are less $0.01(n=7)$. For the TPL+/TPL and the TPL+/TPL- pairs, $P$-values are less than $0.005(n=7)$ for siRNA\#1. For siRNA\#2, $P$-values are 0.15 and 0.01 for the TPL+/TPL and the TPL+/TPL- comparisons, respectively $(n=7)$. All data are presented as mean with SD. Independent two-sample t-test was used for statistical analysis. (C) Western blot analysis of the PCBP2 knockdown in $293 \mathrm{~T}$ and Huh7 cells. GADPH and elF3c used as loading controls. elF4G2 increase, if any, is marginal. (D) Kinetics of the selected reporters' translation in Huh7 cells. Data of a representative experiment are shown. Note that no deceleration of the elF4G2 or CCNI reporter translation is observed in control cells.

elF4G2 down-regulation in all three data sets. To address if this mRNA is really an elF4G2 target and if the elF4G2 dependence is provided solely by the $5^{\prime}$-UTR of the PCBP2 mRNA, we transfected several mRNA reporters, including one bearing the elF4G2-dependent $5^{\prime}$-UTR of the mMap3k3 mRNA (Sugiyama et al. 2017) into NIH/3T3 cells where the elF4G2 gene was knocked out via a CRISPR/ Cas9 approach (Fig. 4A,B). Indeed, the mPCBP2 and mMap3k3 reporters are translated less efficiently in the elF4G2-depleted cells (Fig. 4C). However, the PCBP2 pro- tein level is not apparently altered (Fig. 4B). To address this apparent inconsistency, we knocked down the elF4G2 gene in 293T and Huh7 cells (Fig. 4D) and found that the efficiencies of both mPCBP2 and mMap3k3 reporters' translation are markedly reduced (Fig. 4E) as well as the endogenous PCBP2 level (Fig. 4D). Kinetics of the reporters' expression is not altered in 293T cells (Fig. 4F) and Huh7 or $\mathrm{NIH} / 3 \mathrm{~T} 3$ cells (data not shown). Moreover, a transient elF4G2 knockdown in NIH/3T3 cells also leads to a decrease in the PCBP2 protein level. Allegedly, our 
A

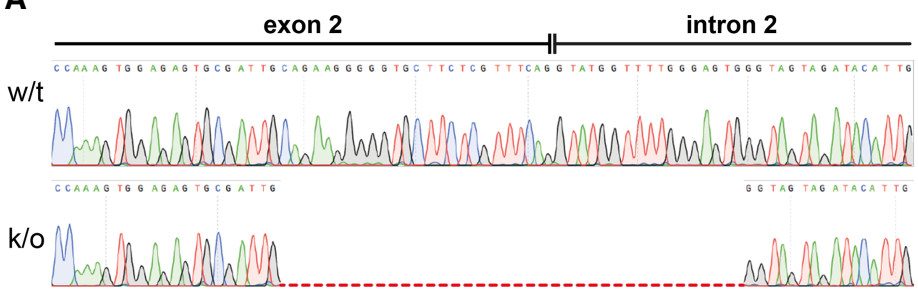

B

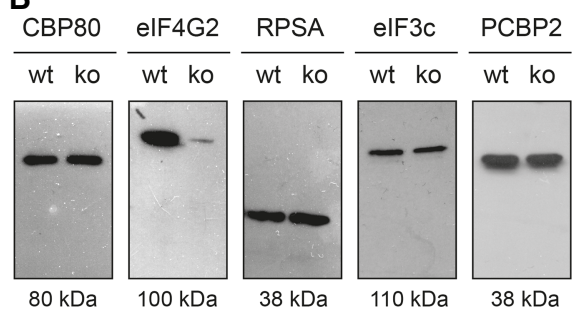

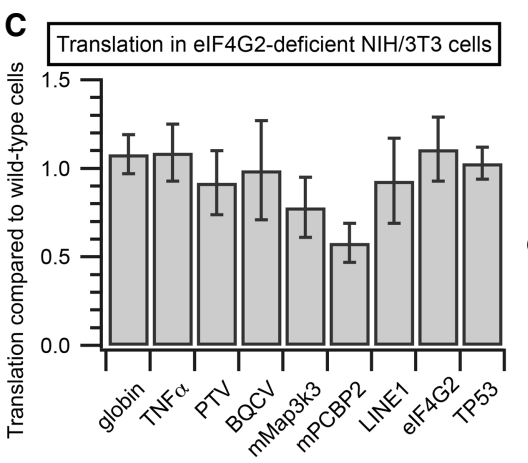

D Western blotting of 293T, Huh7 and NIH/3T3 cells treated with siRNA against elF4G2
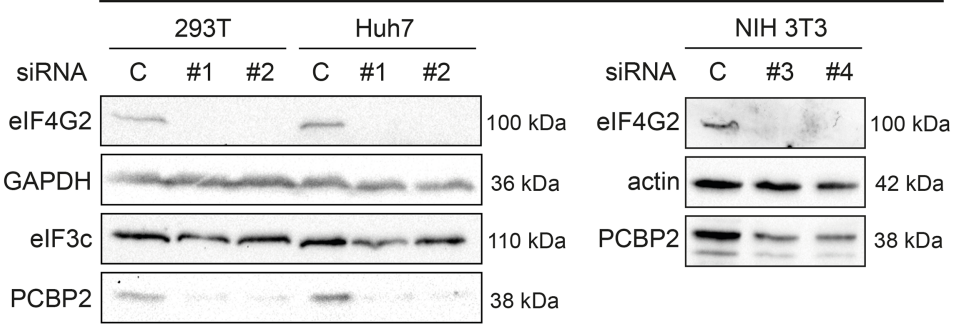

$\mathbf{E}$
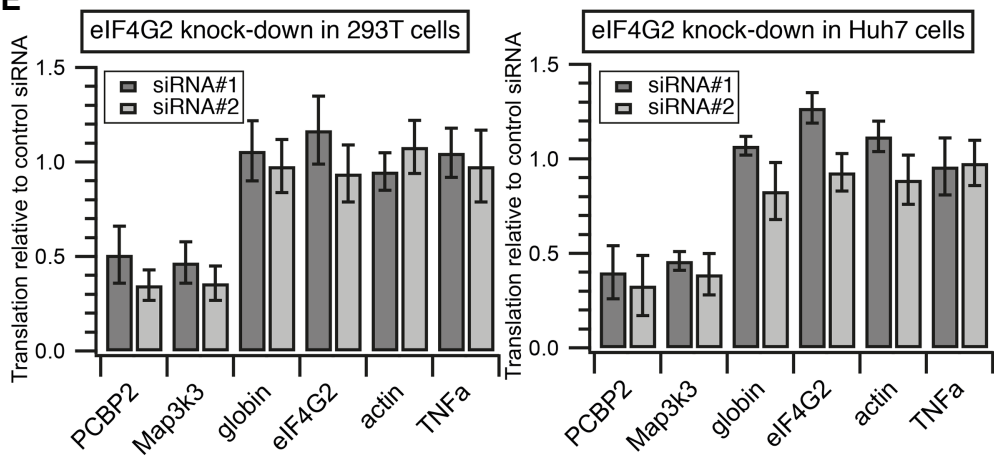

$\mathbf{F}$
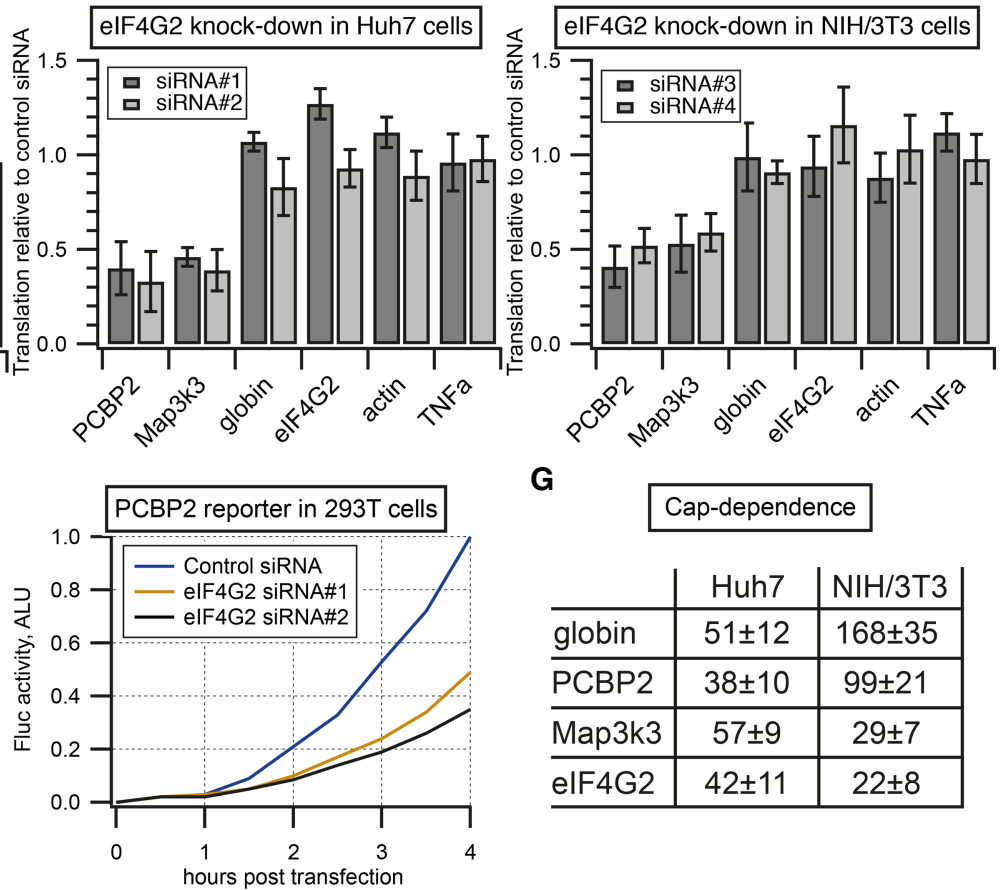

G

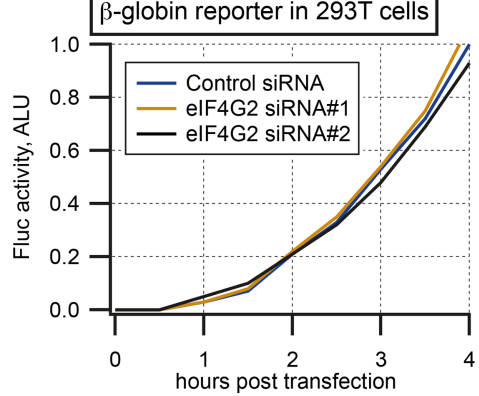

\begin{tabular}{l|c|c|} 
& Huh7 & NIH/3T3 \\
\hline globin & $51 \pm 12$ & $168 \pm 35$ \\
\hline PCBP2 & $38 \pm 10$ & $99 \pm 21$ \\
\hline Map3k3 & $57 \pm 9$ & $29 \pm 7$ \\
\hline elF4G2 & $42 \pm 11$ & $22 \pm 8$ \\
\hline
\end{tabular}

FIGURE 4. The elF4G2 knockout leads to a decreased translation driven by the $5^{\prime}$-UTR of the PCBP2 mRNA in NIH/3T3 cells. (A) The elF4G2 gene sequencing from the wild-type and the elF4G2-deficient NIH/3T3 cells. The indel has occurred right at the junction of exon 2 and intron 2 , which results in a deletion of the splice site. (B) Western blot analysis of the wild-type and elF4G2-deficient NIH/3T3 cells. (C) Comparison of the translation efficiencies of the indicated reporter mRNAs in the elF4G2-deficient vs. wild-type $\mathrm{NIH} / 3 \mathrm{~T} 3$ cells. Bars show translation in the cells lacking elF4G2 relative to the wild-type cells. Note that here no further normalization has been performed and the elF4G2-unresponsive mRNAs are indeed translated with similar efficiencies in either wild-type or knocked out cells. The decreases in the translation of the Map3k3 ( $P$-value $=0.01, n=$ 5 ) and PCBP2 ( $P$-value $=0.0001, n=5$ ) reporters are statistically significant. $(D)$ Western blotting of 293T, Huh7, and NIH/3T3 cells transfected with siRNAs against elF4G2. (E) Indicated in vitro transcribed $\mathrm{m}^{7} \mathrm{G}$-capped and polyadenylated reporters were transfected into 293T, Huh7, and NIH/ $3 \mathrm{~T} 3$ cells pretreated either with the indicated siRNA against the elF4G2 or with the control siRNA. Bars show the translation level relative to control cells. The decrease in the Map3k3 and PCBP2 translation efficiencies is statistically significant ( $P$-values do not exceed $0.0001, n=5)$. $(F)$ Kinetics of the selected reporters' translation in 293T cells. A representative experiment is shown. Note that no deceleration of the PCBP2 reporter translation is observed. All transfection data are present as mean with SD. Independent two-sample t-test was used for statistical analysis. (G) Cap dependence of translation of the selected mRNA reporters in Huh7 and NIH/3T3 cells was calculated as a ratio of $\mathrm{m}^{7} \mathrm{G}$-capped to A-capped mRNA translation efficiencies. Data presented as mean with SD; at least three independent transfections. 
elF4G2-deficient NIH/3T3 cells have restored the PCBP2 level, which highlights the importance of this protein. Overall, these data show that elF4G2 is important for the PCBP2 mRNA translation.

It was suggested that elF4G2 affects its own cap-independent translation (Lewis et al. 2008; Yoffe et al. 2016). Arguably, such an interpretation could have arisen from inadequate use of bicistronic assay and hairpin-containing reporters (Jackson 2013; Terenin et al. 2017). Our data show that the translation of the $\mathrm{m}^{7} \mathrm{G}$-capped reporter mRNA with the $5^{\prime}$-UTR and $3^{\prime}$-UTR of the human elF4G2 mRNA is not affected by the elF4G2 knockout or knockdown, at least under commonly used growth conditions. Notably, both elF4G2-dependent reporters used here (namely, mPCBP2 and mMap3k3) exhibit rather high cap dependence, i.e., stimulation of their translation by the $\mathrm{m}^{7} \mathrm{G}$-cap compared to the nonfunctional A-cap (Fig. 4G), indicating that elF4G2 works on these mRNAs in a cap-dependent fashion as well. In line with this finding, de la Parra and colleagues just recently proposed that elF4G2 is involved in a cap-dependent translation of about $20 \%$ of cellular mRNAs (de la Parra et al. 2018).

\section{Conclusions}

The pyrimidine-rich tract can be found in the $5^{\prime}$-UTRs of the elF4G2 mRNAs from mammals, probably in lancelet, axolotl, at least from certain birds, yet it is not evident in mollusks, insects, or hydra, although homologs of the poly( $\mathrm{rC}$ )-binding proteins are present in all these organisms. Thus, the regulation of the elF4G2 synthesis by PCBP2 may be quite an ancient mechanism. Most probably, PCBP2 hampers a ribosomal scanning and/or a ribosome attachment to an mRNA. Notably, the PCBP2 isoform $\mathrm{f}$ but not the isoform e inhibits elF4G2 translation, while both inhibit CCNI translation. Thus, this study shows for the first time that not all seven PCBP2 isoforms are created equal and they do not have the same mRNA targets. Autoregulatory systems have been described that control translation of the elF1 (Ivanov et al. 2010), elF5 (Loughran et al. 2012), and PABP (de Melo Neto et al. 1995) mRNAs. This list is now expanded by the addition of elF4G2, which controls its own translation via the mRNA-binding protein. However, the regulation swing is not exactly dramatic, and this feedback loop probably serves for fine-tuning of the elF4G2 and PCBP2 expression. elF4G2 is implicated in a cap-independent translation, but our data show that it participates in a capdependent translation as well, since at least some of its target mRNAs (PCBP2 and Map3k3) heavily rely on the $m^{7} G$ cap. In addition, our case raises the possibility that at least some of the reported effects of the elF4G2 depletion may originate from changes in mRNA metabolism due to an altered pattern of mRNA-binding proteins rather than to a genuine elF4G2 activity in translation initiation.

\section{MATERIALS AND METHODS Plasmids}

HuR, PCBP1, PCBP2, and SERBP1 coding sequences were amplified with the appropriate primers using CDNA obtained from RKO cells. The primers' sequences are: HuRfw 5'-AAAAGATCTATGT CTAATGGTTATGAAGACCACAT-3', HuRr 5'-AGACTCGAGTTT ATTTGTGGGACTTGTTGGTTTTGAA-3', PCBP1fw 5'-TCGCCAT GGATGCCGGTGTGACTGAAA-3', PCBP1r 5'-TTTCTCGAGTTT AGCTGCACCCCATGCCCTTCTCA-3', PCBP2fw 5'-ACAGGATC CATGGACACCGGTGTGATTG-3', PCBP2r 5'-CCGCTCGAGTC TAGCTGCTCCCCATGCCACCCGTCT-3', SERBPfw 5'-ACAGGA TCCATGCCTGGGCACTTACAGGAA-3', SERBPr 5'-TTACTCGA GTTTAAGCCAGAGCTGGGAATGCCT-3'.

The PCBP2 amplification resulted in two isoforms, namely, isoforms e and f (NP_001122384 and NP_001122385, respectively). All these sequences were cloned into the homemade pGEX-TEV plasmid, which is essentially pGEX-6p-1 (GE Healthcare) with a TEV cleavage site between the GST coding sequence and MCS. pET16b-hnRNPK (which encodes the human hnRNP K isoform a, NP_112553) was a gift from D. Ostareck (Ostareck et al. 1997). A plasmid for the PTBP1 expression was a gift from C.U.T. Hellen (Hellen et al. 1994).

A plasmid with the BQCV IRES was a gift from P. Lidsky (UCSF). The late adenovirus TPL (Smirnova et al. 2016), poliovirus IRES (Andreev et al. 2012), PTV IRES (Pisarev et al. 2004), and rabbit $\beta$-globin 5'-UTR (Smirnova et al. 2016) reporters have been described previously. $5^{\prime}$ termini of the cloned $5^{\prime}$-UTRs were recreated on the basis of the appropriate CAGE and EST data (Severin et al. 2014). The 5'-UTRs of the human CCNI (5' end corresponds to chr4 77997142), elF4G2 (chr11, 10830470), TIAL1 (chr10, 121356188), TNF $\alpha$ (chr6, 31543342), and TP53 (chr17, 7590805) mRNAs were amplified from RKO or 293T cells cDNA (positions are given for hg19 assembly). The 5'-UTRs of the murine PCBP2 (chr15, 102300970, mm9 assembly) and Map3k3 (chr11, 105945908) mRNAs were amplified using $\mathrm{NIH} / 3 \mathrm{~T} 3$ cells' cDNA. In the elF4G2 $\Delta \mathrm{CU}$ deletion, mutant nucleotides corresponding to 199-276 of the annotated transcript (NM_001418.3) or 10808760-10808837 of the genomic sequence (hg19) were substituted for Hindlll site. Primers used for the amplification of the $5^{\prime}$-UTRs are as follows: mMap3k3fw 5'-AAAACGCGTTAATACGACTCACTATAGGGAGCGTCTTCTGG ACTTCAGGA-3', mMap3k3r 5'-AATGCCTCTTGTTCATCCATG GT-3', mPCBP2fw AAAACGCGTTAATACGACTCACTATAGGG CCCAGACCAGCAGAGGCAGCA, mPCBP2r 5'-ATTTCCATGGC TAGCAGTTACAGGGAGCTGGACTTT-3', CCNIfw 5'-TCTTGGT ACCTAATACGACTCACTATAGGGCTCCCTCCCCAGCCTTCCC CGCGA-3', CCNIr 5'-AACGAAATCTTCGAGTGTGAAGACCCTA GTGATTGCCTTTTCCAACA-3', TNFa5fw 5'-CTTACGCGTTAAT ACGACTCACTATAGGAGCAGACGCTCCCTCAGCAAGGACA-3', TNFa5r 5'-TGTCCATGGTGTCCTTTCCAGGGGAGA-3', TP53 5fw 5'-CTTACGCGTTAATACGACTCACTATAGGAAAAGTCTAG AGCCACCGTCCA-3', TP53_5r 5'-CCTCCATGGCAGTGACCCG GAA-3', DAP5_5fw 5'-ATCTTACGCGTTAATACGACTCACTATA GGCAGTGAGTCGGAGCTCTATGGAGGTG-3', DAP5_5r 5'-TT CTTTATGTTTTTGGCGTCTTCCGCGGCACCCCCTTCTGCAATC GCA-3', TIALfw 5'-CTTACGCGTTAATACGACTCACTATAGGCC ATTTTGTTCATCCTCCTCCT-3', TIALr 5'-TGTCCATGGTGGGT GCGACGGAGCGAT-3'. The elF4G2 and CCNI reporters included parts of the corresponding coding regions. The $\beta$-actin, TP53, 
and TNF $\alpha$ reporters included the authentic $3^{\prime}$-UTRs, and the elF4G2 reporter contained either authentic or SV40 3'-UTR, as indicated. The following primers were used for amplification of the 3'-UTRs: TNFa3fw 5'-ACATCTAGAGGAGGACGAACAT CCAACCTT-3', TNFa3r 5'-AACTTGTTTATTGCAGCTTATAATG GCTAAGCAAACTTTATTTCTCGCCA-3', TP53_3fw 5'-AACAAC TAGTCATTCTCCACTTCTTGTTCCCCACT-3', TP53_3r 5'-GTTG TTAACTTGTTTATTGCAGCTTATAATGGCACCCCTCAGACACA CAGGTGGCA-3', DAP5_3fw 5'-ACATCTAGAACCAGCCAAAGC CTTAAATT-3', DAP5_3r 5'-TATGTTAACTTGTTTATTGCAGCTT ATAATGGTCACTACATCAAGTATCACAATGTTTATT-3', actin_ 3fw 5'-AACATCTAGAGCGGACTATGACTTAGTTGCGTTA-3', actin_3r 5'-GTTGTTAACTTGTTTATTGCAGCTTATAATGGTAAG GTGTGCACTTTTATTCAACTGGTCTCAA-3'. To create the TPL+ and TPL- reporters, the polypyrimidine tract corresponding to nucleotides 199-276 of the human elF4G2 mRNA was amplified with the primers bearing HindIII sites and inserted in the HindIII site of TPL (position 203 of the 235-nt-long TPL), in either sense (TPL+) or antisense (TPL-) orientation. All the UTRs were cloned in pGL3 vector (Promega) upstream of firefly luciferase (FLuc) coding sequence, with the exception of CCNI, in which $5^{\prime}$-UTR was cloned into pNL1.1 vector (Promega) upstream of NanoLuc luciferase (NLuc) coding sequence.

\section{Analysis of ENCODE data}

Data sets ENCSR339FUY, which includes two replicates of the PCBP2 eCLIP data in HepG2 cells, and ENCSR115GAA (mock input control) were analyzed. The aligned reads (ENCFF803OKO. bam, ENCSR339FUY.bam, ENCFF190ITO.bam) were sorted using the GenomicAlignments package (Lawrence et al. 2013). The iCLIP data obtained from Huh7 cells were taken from the GEO data set GSE59840.

\section{RNA pull-down assay}

RNAs were synthesized using MEGAscript T7 Transcription Kit (Ambion) as suggested by the manufacturer with an addition of $0.75 \mathrm{mM}$ biotin-16-UTP (Jena Bioscience). Note that noncapped RNAs were used for the RNA pull-down. The latter was performed as described previously (Andreev et al. 2012) with minor modifications. A total of $300 \mathrm{pmol}$ of the biotinylated RNA was added to a mixture that contained $200 \mu \mathrm{L}$ ( $30 \mathrm{mg}$ of total protein) of HeLa cytoplasmic extract (CilBiotech, Belgium), 80 U Ribolock RNase inhibitor (Thermo Fisher), complete EDTA-free protease inhibitor cocktail (Roche) in buffer "B" [100 mM KCl, 20 mM Tris- $\mathrm{HCl}, \mathrm{pH}$ 7.5, $1 \mathrm{mM} \mathrm{Mg}(\mathrm{OAc})_{2}, 1 \mathrm{mM} \mathrm{DTT}$, and 0.05\% NP40], up to a total volume of $400 \mu \mathrm{L}$. The mixture was incubated in a $2-\mathrm{mL}$ tube with gentle agitation for $30 \mathrm{~min}$ at $30^{\circ} \mathrm{C}$. Meanwhile, Streptavidin Sepharose High Performance (GE Healthcare) suspension (50 $\mu \mathrm{L}$ per reaction) was washed four times with buffer " $A$ " [100 mM, $20 \mathrm{mM}$ Tris- $\mathrm{HCl}, \mathrm{pH} 7.5,5 \mathrm{mM} \mathrm{Mg}(\mathrm{OAc})_{2}, 1 \mathrm{mM}$ DTT, and $0.05 \%$ NP40], resuspended in $1300 \mu \mathrm{L}$ of buffer " $\mathrm{A}$," and added to the lysate with RNA. After $2 \mathrm{~h}$ of gentle shaking on ice, the resin was washed extensively with buffer " $B$," then resuspended in $80 \mu \mathrm{L}$ of buffer "B" supplemented with $2 \mathrm{mM} \mathrm{CaCl}_{2}$ and $450 \mathrm{U}$ of micrococcal nuclease (Thermo Fisher). RNA was digested for $30 \mathrm{~min}$ at $37^{\circ} \mathrm{C}$. Eluted proteins were separated by SDS-PAGE and their identities were determined by LC-MS.

\section{Protein expression in E. coli}

PCBP2e, PCBP2f, HuR, SERBP1, and PCBP1 were expressed in Rosetta-gami 2 cells (Novagen) at $15^{\circ} \mathrm{C}$ overnight after the induction by $50 \mu \mathrm{M}$ IPTG $\left(10 \mu \mathrm{M}\right.$ for PCBP1) at $\mathrm{OD}_{600} \approx 0.5$. hnRNP K was expressed in Rosetta2 (DE3) similarly with the only exception that the expression was induced by $1 \mathrm{mM}$ IPTG. HuR, PCBP1, PCBP2e, PCBP2f, and SERBP1 were expressed as GST-fusions and eluted from Glutathione Sepharose 4B (GE Healthcare) with a homemade TEV protease. A pure hnRNP K was obtained as a 200-300 mM imidazole elution fraction from Ni Sepharose High Performance (GE Healthcare). All proteins were dialyzed against A100 buffer $(20 \mathrm{mM}$ Tris- $\mathrm{HCl}, \mathrm{pH} 7.5,100 \mathrm{mM} \mathrm{KCl}, 0.5 \mathrm{mM}$ EDTA, $1 \mathrm{mM}$ DTT, 10\% glycerol), with the exception of hnRNP $K$, which was purified and stored in buffers containing $20 \%$ glycerol, in order to prevent the protein aggregation. PTBP1 was expressed and purified as previously described (Hellen et al. 1994).

\section{siRNAs}

The siRNAs were designed using in-house software based on common principles (Reynolds et al. 2004; Fakhr et al. 2016) to improve efficacy and potency, and to exclude off-target effects. siRNAs were assembled using automated DNA/RNA synthesizer by 2'-TBDMS/phosphoramidite chemistry, purified by ionexchange HPLC (Noll et al. 2011), and verified by ESI-MS. Duplexes were annealed in $50 \mathrm{mM} \mathrm{KOAc}$ water solution by heating to $80^{\circ} \mathrm{C}$ for $5 \mathrm{~min}$ followed by slow cooling to room temperature. Cells were transfected in $60 \mathrm{~mm}$ or $35 \mathrm{~mm}$ plates with the corresponding duplexes using Lipofectamine RNAiMAX (Invitrogen) at a final concentration in the medium $10 \mathrm{nM}, 48 \mathrm{~h}$ prior to replating cells into a 24 -well plate at $~ 30 \%-40 \%$ confluency; the latter coincided with another round of siRNA transfection. Twenty-four hours later (i.e., $72 \mathrm{~h}$ after the first siRNA transfection), mRNAs were transfected, as described below. Sequences of the siRNAs are (capital letters stand for unmodified ribonucleotides and lowercase denote 2'-OMe protected ribonucleotides): \#1fw cuGAGAGAAuuAucAcuuudTsdT, \#1rev AAAGUGAuAAUUCUC UcAGdTsdT, \#2fw ucAucGGAAAGAAAGGAGAdTsdT, \#2r, UC UCCUUUCUUUCCGAUGAdTsdT, \#3fw GcGccAAAAucAAuGA GAudTsdT, \#3r AUCUcAUUGAUUUUGGCGCdTsdT for the PCBP2 knockdown, and \#1fw cuccuuAAAcuAAcuGAAAdTsdT, \#1rev UUUcAGUuAGUUuAAGGAGdTsdT, \#2fw cAAucAAAuuc GucAAGAudTsdT, \#2rev AUCUUGACGAAUUUGAUUGdTsdT for the elF4G2 knockdown in human cells, and \#3fw GcAcAA AcuGAucAGuuudTsdT, \#3rev AAACUGAUcAGUUUUGuGCdT sdT, \#4fw AuAcuuGAGuuGuuGcAAudTsdT, \#4rev AUUGcAAcA ACUcAAGuAUdTsdT for the elF4G2 knockdown in murine cells. The control siRNA duplex was reconstituted from 5'-cAGcuGuA uucAuAAuuuATsdT-3' and 5'-uAAAUuAUGAAuAcAGCUGdTs dT-3' oligonucleotides.

\section{mRNA transcription, in vitro translation and transfection}

Templates for in vitro transcription were prepared via PCR, which enabled the introduction of the 50-nt-long poly(A) tail to all mRNAs used throughout the study. PCR products were purified with Wizard SV Gel and PCR Clean-Up System (Promega). 
mRNAs were synthesized using T7 RiboMAX Large Scale RNA Production System (Promega) in reactions that contained either $3^{\prime}$-O-Me-m GpppG (ARCA) or ApppG (both from NEB) cap analogs. RNAs were purified via $2 \mathrm{M} \mathrm{LiCl}$ precipitation. Translation in Krebs-2 ascites carcinoma cells S30 extract was performed essentially as described previously (Dmitriev et al. 2009). Recombinant proteins were added to the translation reactions prior to mRNA without any preincubation. Transfection was performed in a 24-well plate as previously described (Andreev et al. 2013), with minor modifications that included lesser mRNA per well (100 $\mathrm{ng}$ instead of $200 \mathrm{ng}$ ) and use of $5 \mathrm{ng}$ of $\mathrm{m}^{7} \mathrm{G}$-capped $\beta$-globin-Nluc mRNA (instead of Rluc) as a reference for reporters coding for Fluc, or $\mathrm{m}^{7} \mathrm{G}$-capped $\beta$-globin-Fluc mRNA for reporters coding for Nluc. Relative translation efficiency was calculated for each mRNA as a reporter to reference ratio. For the kinetic analyses of transfected reporters' expression, mRNAs were transfected in several wells in parallel, and then translation was stopped by addition of cycloheximide up to $100 \mu \mathrm{g} / \mathrm{mL}$ at the indicated time points. Luciferases' activities were measured using Dual-Luciferase Reporter, Luciferase, or Nano-Glo DualLuciferase Assay Systems (all Promega) where appropriate.

\section{Knocking out elF4G2 gene in NIH/3T3 cells}

gRNAs were designed at http://crispr.mit.edu/ and inserted into a pX458 vector (Ran et al. 2013). NIH/3T3 cells were transfected with the resulting vector, sorted for GFP presence, and seeded into a 96-well plate. The monoclonal cells were analyzed by PCR sequencing and western blotting against elF4G2. The sequencing showed that the deletion occurred at the border of exon 2 and intron 2, resulting in a disruption of the splice site (Fig. 4A). Translation of the corresponding mRNA leads to termination just at the beginning of intron 2, resulting in a short MESAIG peptide synthesis.

\section{Antibodies}

elF4G2 (Bethyl laboratories, A302-239A), CBP80 (Bethyl laboratories, A301-793A), elF3c (Santa Cruz Biotechnology, sc-74507), PCBP2 (Abnova, H00005094-M05), anti-GADPH (Proteintech Group Inc, 10494-1-AP; or ZG003, Invitrogen), $\beta$-actin (Abcam, ab8229), and anti-RPSA antibodies were raised in mouse against full-length $\mathrm{His}_{6}$-tagged human RPSA protein expressed in E. coli. Western blots were exposed to Kodak X-ray film or visualized via a Bio-Rad ChemiDoc XRS+ Molecular Imager.

\section{ACKNOWLEDGMENTS}

We are indebted to Ivan Kulakovsky (EIMB RAS) and Irina Eliseeva (Institute of Protein Research) for their help with the ribosome footprint profiling analysis. We thank Gene Yeo (UCSD) for sharing the PCBP2 eCLIP data via the ENCODE Consortium. We are grateful to Peter Lidsky (UCSF) for the plasmid encoding the BQCV IRES, Cristopher Ulrich Tristram Hellen (SUNY) for the PTBP1, and Dirk Ostareck (University Hospital Aachen) for the hnRNP K expression plasmids. Work was supported by grants from the Russian Science Foundation (19-14-00152) to I.N.S. (mechanism of elF4G2-driven translation) and the Russian
Foundation for Basic Research (16-04-01628) to I.M.T. (role of PCBP2 in translation regulation).

Received February 26, 2018; accepted March 18, 2019.

\section{REFERENCES}

Andreev DE, Dmitriev SE, Terenin IM, Prassolov VS, Merrick WC, Shatsky IN. 2009. Differential contribution of the $m^{7} G$-cap to the $5^{\prime}$ end-dependent translation initiation of mammalian mRNAs. Nucleic Acids Res 37: 6135-6147. doi:10.1093/nar/gkp665

Andreev DE, Hirnet J, Terenin IM, Dmitriev SE, Niepmann M, Shatsky IN. 2012. Glycyl-tRNA synthetase specifically binds to the poliovirus IRES to activate translation initiation. Nucleic Acids Res 40: 5602-5614. doi:10.1093/nar/gks182

Andreev DE, Dmitriev SE, Terenin IM, Shatsky IN. 2013. Cap-independent translation initiation of apaf-1 mRNA based on a scanning mechanism is determined by some features of the secondary structure of its $5^{\prime}$ untranslated region. Biochemistry (Mosc) 78: 157165. doi:10.1134/S0006297913020041

Asnani M, Pestova TV, Hellen CUT. 2016a. Initiation on the divergent Type I cadicivirus IRES: factor requirements and interactions with the translation apparatus. Nucleic Acids Res 44: 3390-3407. doi:10.1093/nar/gkw074

Asnani M, Pestova TV, Hellen CUT. 2016b. PCBP2 enables the cadicivirus IRES to exploit the function of a conserved GRNA tetraloop to enhance ribosomal initiation complex formation. Nucleic Acids Res 44: 9902-9917. doi:10.1093/nar/gkw074

Baltz AG, Munschauer M, Schwanhäusser B, Vasile A, Murakawa Y, Schueler M, Youngs N, Penfold-Brown D, Drew K, Milek M, et al. 2012. The mRNA-bound proteome and its global occupancy profile on protein-coding transcripts. Mol Cell 46: 674-690. doi:10 .1016/j.molcel.2012.05.021

Barreau C, Dutertre S, Paillard L, Osborne HB. 2006. Liposome-mediated RNA transfection should be used with caution. RNA 12: 1790-1793. doi:10.1261/rna.191706

Beckmann BM, Horos R, Fischer B, Castello A, Eichelbaum K, Alleaume A-M, Schwarzl T, Curk T, Foehr S, Huber W, et al. 2015. The RNA-binding proteomes from yeast to man harbour conserved enigmRBPs. Nat Commun 6: 10127. doi:10.1038/ ncomms10127

Blyn LB, Chen R, Semler BL, Ehrenfeld E. 1995. Host cell proteins binding to domain IV of the $5^{\prime}$ noncoding region of poliovirus RNA. J Virol 69: 4381-4389.

Blyn LB, Swiderek KM, Richards O, Stahl DC, Semler BL, Ehrenfeld E. 1996. Poly $(r C)$ binding protein 2 binds to stem-loop IV of the poliovirus RNA 5' noncoding region: identification by automated liquid chromatography-tandem mass spectrometry. Proc Natl Acad Sci 93: 11115-11120. doi:10.1073/pnas.93.20.11115

Blyn LB, Towner JS, Semler BL, Ehrenfeld E. 1997. Requirement of poly $(\mathrm{rC})$ binding protein 2 for translation of poliovirus RNA. J Virol 71: 6243-6246.

Castello A, Fischer B, Eichelbaum K, Horos R, Beckmann BM, Strein C, Davey NE, Humphreys DT, Preiss T, Steinmetz LM, et al. 2012. Insights into RNA biology from an atlas of mammalian mRNAbinding proteins. Cell 149: 1393-1406. doi:10.1016/j.cell.2012 .04 .031

Choi HS, Hwang CK, Song KY, Law P-Y, Wei L-N, Loh HH. 2009. Poly (C)-binding proteins as transcriptional regulators of gene expression. Biochem Biophys Res Commun 380: 431-436. doi:10 .1016/j.bbrc.2009.01.136

Collier B, Goobar-Larsson L, Sokolowski M, Schwartz S. 1998. Translational inhibition in vitro of human papillomavirus type 16 L2 mRNA mediated through interaction with heterogenous 


\section{Smirnova et al.}

ribonucleoprotein $\mathrm{K}$ and poly(rC)-binding proteins 1 and 2. J Biol Chem 273: 22648-22656. doi:10.1074/jbc.273.35.22648

de la Parra C, Ernlund A, Alard A, Ruggles K, Ueberheide B, Schneider RJ. 2018. A widespread alternate form of cap-dependent mRNA translation initiation. Nat Commun 9: 3068. doi:10 .1038/s41467-018-05539-0

de Melo Neto OP, Standart N, Martins de Sa C. 1995. Autoregulation of poly(A)-binding protein synthesis in vitro. Nucleic Acids Res 23: 2198-2205. doi:10.1093/nar/23.12.2198

Dmitriev SE, Andreev DE, Terenin IM, Olovnikov IA, Prassolov VS, Merrick WC, Shatsky IN. 2007. Efficient translation initiation directed by the 900-nucleotide-long and GC-rich $5^{\prime}$ untranslated region of the human retrotransposon LINE-1 mRNA is strictly cap dependent rather than internal ribosome entry site mediated. Mol Cell Biol 27: 4685-4697. doi:10.1128/MCB.02138-06

Dmitriev SE, Andreev DE, Adyanova ZV, Terenin IM, Shatsky IN. 2009. Efficient cap-dependent in vitro and in vivo translation of mammalian mRNAs with long and highly structured 5'-untranslated regions. Mol Biol 43: 108-113. doi:10.1134/S0026893309010154

ENCODE Project Consortium. 2012. An integrated encyclopedia of DNA elements in the human genome. Nature 489: 57-74. doi:10.1038/nature11247

Expert-Bezançon A, Le Caer JP, Marie J. 2002. Heterogeneous nuclear ribonucleoprotein (hnRNP) $\mathrm{K}$ is a component of an intronic splicing enhancer complex that activates the splicing of the alternative exon 6A from chicken $\beta$-tropomyosin pre-mRNA. J Biol Chem 277: 16614-16623. doi:10.1074/jbc.M201083200

Fakhr E, Zare F, Teimoori-Toolabi L. 2016. Precise and efficient siRNA design: a key point in competent gene silencing. Cancer Gene Ther 23: 73-82. doi:10.1038/cgt.2016.4

Flynn RA, Martin L, Spitale RC, Do BT, Sagan SM, Zarnegar B, Qu K, Khavari PA, Quake SR, Sarnow P, et al. 2015. Dissecting noncoding and pathogen RNA-protein interactomes. RNA 21: 135-143. doi:10.1261/rna.047803.114

Gamarnik AV, Andino R. 1997. Two functional complexes formed by $\mathrm{KH}$ domain containing proteins with the $5^{\prime}$ noncoding region of poliovirus RNA. RNA 3: 882-892.

Graff J, Cha J, Blyn LB, Ehrenfeld E. 1998. Interaction of poly $(\mathrm{rC})$ binding protein 2 with the $5^{\prime}$ noncoding region of hepatitis $A$ virus RNA and its effects on translation. J Virol 72: 9668-9675.

Grelet S, Link LA, Howley B, Obellianne C, Palanisamy V, Gangaraju VK, Diehl JA, Howe PH. 2017. A regulated PNUTS mRNA to IncRNA splice switch mediates EMT and tumour progression. Nat Cell Biol 19: 1105-1115. doi:10.1038/ncb3595

Han W, Xin Z, Zhao Z, Bao W, Lin X, Yin B, Zhao J, Yuan J, Qiang B, Peng $X$. 2013. RNA-binding protein PCBP2 modulates glioma growth by regulating FHL3. J Clin Invest 123: 2103-2118. doi:10 $.1172 / \mathrm{JCl} 61820$

Hein MY, Hubner NC, Poser I, Cox J, Nagaraj N, Toyoda Y, Gak IA, Weisswange I, Mansfeld J, Buchholz F, et al. 2015. A human interactome in three quantitative dimensions organized by stoichiometries and abundances. Cell 163: 712-723. doi:10.1016/j.cell 2015.09.053

Hellen CU, Pestova TV, Litterst M, Wimmer E. 1994. The cellular polypeptide $\mathrm{p} 57$ (pyrimidine tract-binding protein) binds to multiple sites in the poliovirus 5' nontranslated region. J Virol 68: 941 950.

Henis-Korenblit S, Shani G, Sines T, Marash L, Shohat G, Kimchi A. 2002. The caspase-cleaved DAP5 protein supports internal ribosome entry site-mediated translation of death proteins. Proc Natl Acad Sci 99: 5400-5405. doi:10.1073/pnas.082102499

Hentze MW, Castello A, Schwarzl T, Preiss T. 2018. A brave new world of RNA-binding proteins. Nat Rev Mol Cell Biol 19: 327-341. doi:10.1038/nrm.2017.130
Hinnebusch AG. 2011. Molecular mechanism of scanning and start codon selection in eukaryotes. Microbiol Mol Biol Rev 75: 434467. doi:10.1128/MMBR.00008-11

Hinnebusch AG. 2014. The scanning mechanism of eukaryotic translation initiation. Annu Rev Biochem 83: 779-812. doi:10.1146/ annurev-biochem-060713-035802

Hundsdoerfer P, Thoma C, Hentze MW. 2005. Eukaryotic translation initiation factor $4 \mathrm{Gl}$ and $\mathrm{p} 97$ promote cellular internal ribosome entry sequence-driven translation. Proc Natl Acad Sci 102: 13421-13426. doi:10.1073/pnas.0506536102

Imataka H, Olsen HS, Sonenberg N. 1997. A new translational regulator with homology to eukaryotic translation initiation factor $4 \mathrm{G}$. EMBO J 16: 817-825. doi:10.1093/emboj/16.4.817

Ivanov IP, Loughran G, Sachs MS, Atkins JF. 2010. Initiation context modulates autoregulation of eukaryotic translation initiation factor 1 (elF1). Proc Natl Acad Sci 107: 18056-18060. doi:10.1073/pnas 1009269107

Jackson RJ. 2013. The current status of vertebrate cellular mRNA IRESs. Cold Spring Harb Perspect Biol 5: a011569. doi:10.1101/ cshperspect.a011569

Ji X, Park JW, Bahrami-Samani E, Lin L, Duncan-Lewis C, Pherribo G, Xing Y, Liebhaber SA. 2016. $\alpha$ CP binding to a cytosine-rich subset of polypyrimidine tracts drives a novel pathway of cassette exon splicing in the mammalian transcriptome. Nucleic Acids Res 44: 2283-2297. doi:10.1093/nar/gkw088

Kiledjian M, Wang X, Liebhaber SA. 1995. Identification of two KH domain proteins in the $\alpha$-globin mRNP stability complex. EMBO J 14: 4357-4364. doi:10.1002/j.1460-2075.1995.tb00110.x

Lawrence M, Huber W, Pagès H, Aboyoun P, Carlson M, Gentleman R, Morgan MT, Carey VJ. 2013. Software for computing and annotating genomic ranges. PLoS Comput Biol 9: e1003118. doi:10 .1371/journal.pcbi.1003118

Lee SH, McCormick F. 2006. p97/DAP5 is a ribosome-associated factor that facilitates protein synthesis and cell proliferation by modulating the synthesis of cell cycle proteins. EMBO J 25: 40084019. doi:10.1038/sj.emboj.7601268

Lee P-T, Liao P-C, Chang W-C, Tseng JT. 2007. Epidermal growth factor increases the interaction between nucleolin and heterogeneous nuclear ribonucleoprotein $\mathrm{K} / \mathrm{poly}(\mathrm{C})$ binding protein 1 complex to regulate the gastrin mRNA turnover. Mol Biol Cell 18: 5004-5013. doi:10.1091/mbc.e07-04-0384

Levy-Strumpf N, Deiss LP, Berissi H, Kimchi A. 1997. DAP-5, a novel homolog of eukaryotic translation initiation factor $4 \mathrm{G}$ isolated as a putative modulator of $\gamma$ interferon-induced programmed cell death. Mol Cell Biol 17: 1615-1625. doi:10.1128/MCB.17.3.1615

Lewis SM, Cerquozzi S, Graber TE, Ungureanu NH, Andrews $\mathrm{M}$, Holcík M. 2008. The elF4G homolog DAP5/p97 supports the translation of select mRNAs during endoplasmic reticulum stress. Nucleic Acids Res 36: 168-178. doi:10.1093/nar/gkm1007

Loughran G, Sachs MS, Atkins JF, Ivanov IP. 2012. Stringency of start codon selection modulates autoregulation of translation initiation factor elF5. Nucleic Acids Res 40: 2898-2906. doi:10.1093/nar/ gkr1192

Marash L, Liberman N, Henis-Korenblit S, Sivan G, Reem E, ElroyStein O, Kimchi A. 2008. DAP5 promotes cap-independent translation of $\mathrm{Bcl}-2$ and $\mathrm{CDK} 1$ to facilitate cell survival during mitosis. Mol Cell 30: 447-459. doi:10.1016/j.molcel.2008.03.018

Noll B, Seiffert S, Hertel F, Debelak H, Hadwiger P, Vornlocher H-P, Roehl I. 2011. Purification of small interfering RNA using nondenaturing anion-exchange chromatography. Nucleic Acid Ther 21: 383-393. doi:10.1089/nat.2011.0317

Nousch M, Reed V, Bryson-Richardson RJ, Currie PD, Preiss T. 2007. The elF4G-homolog p97 can activate translation independent of caspase cleavage. RNA 13: 374-384. doi:10.1261/rna.372307 
Ostareck DH, Ostareck-Lederer A, Wilm M, Thiele BJ, Mann M, Hentze MW. 1997. mRNA silencing in erythroid differentiation: hnRNP $\mathrm{K}$ and hnRNP E1 regulate 15-lipoxygenase translation from the $3^{\prime}$ end. Cell 89: 597-606. doi:10.1016/S0092-8674(00) 80241-X

Ostareck-Lederer A, Ostareck DH. 2012. Precision mechanics with multifunctional tools: how hnRNP $\mathrm{K}$ and hnRNPs E1/E2 contribute to post-transcriptional control of gene expression in hematopoiesis. Curr Protein Pept Sci 13: 391-400. doi:10.2174/ 138920312801619484

Pisarev AV, Chard LS, Kaku Y, Johns HL, Shatsky IN, Belsham GJ. 2004. Functional and structural similarities between the internal ribosome entry sites of hepatitis $C$ virus and porcine teschovirus, a picornavirus. J Virol 78: 4487-4497. doi:10.1128/JVI.78.9.44874497.2004

Ran FA, Hsu PD, Wright J, Agarwala V, Scott DA, Zhang F. 2013. Genome engineering using the CRISPR-Cas9 system. Nat Protoc 8: 2281-2308. doi:10.1038/nprot.2013.143

Ren C, Zhang J, Yan W, Zhang Y, Chen X. 2016. RNA-binding protein PCBP2 regulates $p 73$ expression and p73-dependent antioxidant defense. J Biol Chem 291: 9629-9637. doi:10.1074/jbc.M115 .712125

Reynolds A, Leake D, Boese Q, Scaringe S, Marshall WS, Khvorova A. 2004. Rational siRNA design for RNA interference. Nat Biotechnol 22: 326-330. doi:10.1038/nbt936

Scoumanne A, Cho SJ, Zhang J, Chen X. 2011. The cyclin-dependent kinase inhibitor p21 is regulated by RNA-binding protein PCBP4 via mRNA stability. Nucleic Acids Res 39: 213-224. doi:10.1093/ nar/gkq778

Severin J, Lizio M, Harshbarger J, Kawaji H, Daub CO, Hayashizaki Y, FANTOM Consortium, Bertin N, Forrest ARR. 2014. Interactive visualization and analysis of large-scale sequencing datasets using ZENBU. Nat Biotechnol 32: 217-219. doi:10.1038/nbt.2840

Shaughnessy JD, Jenkins NA, Copeland NG. 1997. cDNA cloning, expression analysis, and chromosomal localization of a gene with high homology to wheat elF-(iso)4F and mammalian elF-4G. Genomics 39: 192-197. doi:10.1006/geno.1996.4502

Smirnova W, Terenin IM, Khutornenko AA, Andreev DE, Dmitriev SE, Shatsky IN. 2016. Does HIV-1 mRNA 5'-untranslated region bear an internal ribosome entry site? Biochimie 121: 228-237. doi:10 .1016/j.biochi.2015.12.004

Sugiyama $H$, Takahashi $K$, Yamamoto T, Iwasaki M, Narita $M$, Nakamura M, Rand TA, Nakagawa M, Watanabe A, Yamanaka S. 2017. Nat1 promotes translation of specific proteins that induce differentiation of mouse embryonic stem cells. Proc Natl Acad Sci 114: 340-345. doi:10.1073/pnas.1617234114

Sweeney TR, Abaeva IS, Pestova TV, Hellen CUT. 2014. The mechanism of translation initiation on Type 1 picornavirus IRESs. EMBO J 33: 76-92. doi:10.1002/embj.201386124

Takahashi K, Maruyama M, Tokuzawa Y, Murakami M, Oda Y, Yoshikane N, Makabe KW, Ichisaka T, Yamanaka S. 2005.
Evolutionarily conserved non-AUG translation initiation in NAT1/ p97/DAP5 (EIF4G2). Genomics 85: 360-371. doi:10.1016/j .ygeno.2004.11.012

Terenin IM, Smirnova VV, Andreev DE, Dmitriev SE, Shatsky IN. 2017. A researcher's guide to the galaxy of IRESs. Cell Mol Life Sci 74: 1431-1455. doi:10.1007/s00018-016-2409-5

Thiele B-J, Doller A, Kähne T, Pregla R, Hetzer R, Regitz-Zagrosek V. 2004. RNA-binding proteins heterogeneous nuclear ribonucleoprotein $A 1, E 1$, and $K$ are involved in post-transcriptional control of collagen I and III synthesis. Circ Res 95: 1058-1066. doi:10 $.1161 / 01$. RES.0000149166.33833.08

Thomson DW, Bracken CP, Szubert JM, Goodall GJ. 2013. On measuring miRNAs after transient transfection of mimics or antisense inhibitors. PLoS One 8: e55214. doi:10.1371/journal.pone .0055214

Thyagarajan A, Szaro BG. 2008. Dynamic endogenous association of neurofilament mRNAs with K-homology domain ribonucleoproteins in developing cerebral cortex. Brain Res 1189: 33-42. doi:10.1016/j.brainres.2007.11.012

Uhlen M, Fagerberg L, Hallström BM, Lindskog C, Oksvold P, Mardinoglu A, Sivertsson Å, Kampf C, Sjöstedt E, Asplund A, et al. 2015. Proteomics. Tissue-based map of the human proteome. Science 347: 1260419. doi:10.1126/science.1260419

Walter BL, Nguyen JH, Ehrenfeld E, Semler BL. 1999. Differential utilization of poly $(\mathrm{rC})$ binding protein 2 in translation directed by picornavirus IRES elements. RNA 5: 1570-1585. doi:10.1017/ S1355838299991483

Yamanaka S, Poksay KS, Arnold KS, Innerarity TL. 1997. A novel translational repressor mRNA is edited extensively in livers containing tumors caused by the transgene expression of the apoB mRNAediting enzyme. Genes Dev 11: 321-333. doi:10.1101/gad.11.3 .321

Yamanaka S, Zhang XY, Maeda M, Miura K, Wang S, Farese RV, Iwao $\mathrm{H}$, Innerarity TL. 2000. Essential role of NAT1/p97/DAP5 in embryonic differentiation and the retinoic acid pathway. EMBO J 19: 5533-5541. doi:10.1093/emboj/19.20.5533

Yoffe $Y$, David M, Kalaora R, Povodovski L, Friedlander G, Feldmesser E, Ainbinder E, Saada A, Bialik S, Kimchi A. 2016. Cap-independent translation by DAP 5 controls cell fate decisions in human embryonic stem cells. Genes Dev 30: 1991-2004. doi:10 $.1101 /$ gad.285239.116

Yoshikane N, Nakamura N, Ueda R, Ueno N, Yamanaka S Nakamura M. 2007. Drosophila NAT1, a homolog of the vertebrate translational regulator NAT1/DAP5/p97, is required for embryonic germband extension and metamorphosis. Dev Growth Differ 49: 623-634. doi:10.1111/j.1440-169X.2007 00956.x

Yueh A, Schneider RJ. 1996. Selective translation initiation by ribosome jumping in adenovirus-infected and heat-shocked cells. Genes Dev 10: 1557-1567. doi:10.1101/gad.10.12.1557 

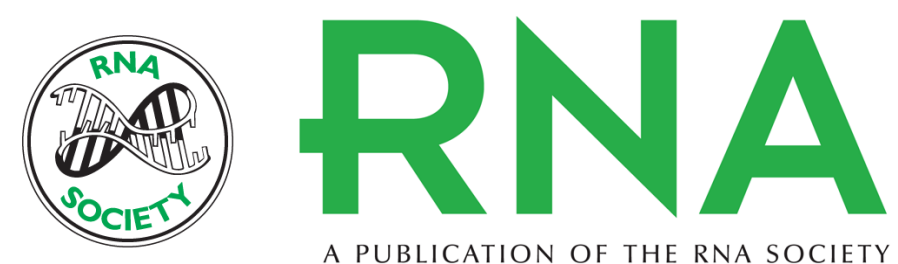

A PUBLICATION OF THE RNA SOCIETY

\title{
elF4G2 balances its own mRNA translation via a PCBP2-based feedback loop
}

\author{
Victoria V. Smirnova, Ekaterina D. Shestakova, Dmitry V. Bikmetov, et al.
}

RNA 2019 25: 757-767 originally published online April 22, 2019

Access the most recent version at doi:10.1261/rna.065623.118

\section{References This article cites 71 articles, 30 of which can be accessed free at: http://rnajournal.cshlp.org/content/25/7/757.full.html\#ref-list-1 \\ Creative This article is distributed exclusively by the RNA Society for the first 12 months after the Commons full-issue publication date (see http://rnajournal.cshlp.org/site/misc/terms.xhtml). After 12 License months, it is available under a Creative Commons License (Attribution-NonCommercial 4.0 International), as described at http://creativecommons.org/licenses/by-nc/4.0/.}

Email Alerting Receive free email alerts when new articles cite this article - sign up in the box at the Service top right corner of the article or click here. 